\title{
PENGEMBANGAN MAKANAN LOKAL MEGONO LAKTAGENIK UNTUK MENINGKATKAN PRODUKSI AIR SUSU IBU DAN MEMACU PERTUMBUHAN BAYI
}

\author{
Indar Widowati*, Hartati, Zaenal Amirudin \\ Program Studi Diploma III Keperawatan Pekalongan Poltekkes Kemenkes Semarang \\ Jl. Perintis Kemerdekaan Pekalongan \\ Koresponden: indarwidowati@gmail.com
}

\begin{abstract}
This researched aims to: 1) Develop local food potentials into innovative product of lactagenic megono food, 2) Analyzed the nutritional content of lactagenic megono product,3) Analyzed the influence of lactagenic megono on increasing breast milk production and infant growth. Methods of this researched include: 1) Hedonic organoleptic perceptive test of three megono recipes derived from the community around Pekalongan. The selected product then tested proximate and intervention was conducted by lactating mothers. The result of hedonic organoleptic test proves that the selected product is A megono recipe, the value of taste attribute got 87 , the aroma got 84 , the texture attribute got 89 and the color attribute got 86 . The proximate test shows that the water content is $79,98 \%$, the ash content is $2,611 \%$, the fat content is $1,653 \%$, the protein level is 2,967 , andthe carbohydrate level is $12,789 \%$. The mean of infant weight in the control group increased until to $3^{\text {rd }}$ weeks by 19.17 grams, in the intervention group of 684.26 grams. The average increase of breast milk volume in the control group was $63.413 \mathrm{ml}$, in the intervention group of $221.413 \mathrm{ml}$. The result of Anova test no difference of infant weight in control group ( $\rho$ value equal to $0,949>0,05$ ), in group of intervention given by megono lactagenichas significant difference ( $\rho$ value equal to $0,048<0,05$ ). There was a significant difference in the volume of breast milk in the control group ( $\rho$ value of $0.025<0.05$ ), in the intervention group ( $\rho$ value of $0.000<0.05$ ).
\end{abstract}

Keywords: Lactagenic megono, Breastmilk production, Infant growth

\section{PENDAHULUAN}

PemberianAir Susu Ibu (ASI) merupakan cara pertama untuk mendapatkan kehidupan yang sehat dan sejahtera bagi setiap manusia. ASI eksklusif memiliki konstribusi yang besar terhadap pertumbuhan dan perkembangan anak secara optimal (Kemenkes RI, 2016).

Namun, belum semua orang menyadari akan manfaat ASI eksklusif bagi bayinya. Di beberapa negara maju dan berkembang, termasuk Indonesia, banyak ibu pekerja (wanita karier) yang tidak menyusui secara eksklusif. Ditambah lagi dengan tingginya aktivitas, tidak adanya waktu untuk memasak makanan dan tuntutan pekerjaan terutama yang tinggal diperkotaan, membuat masyarakat lebih memilih makanan siap olah dan siap santap, yang belum tentu mengandung nilai gizi yang cukup.

Megono merupakan makanan khas Pekalongan yang memiliki potensi untuk dikembangkan. Megono dengan bahan dasar nangka muda, kandungan terbesarnya adalah air dan karbohidrat (Rubatzky dan Yamaguchi, 1998 dalam Anna Amania Khusnayaini, 2011). Untuk itu diperlukan fortifikasizat gizi dan bahan mineral lainnya dengan menambah sumber di luar nangka muda sebagai bahan dasarnya.

Daun katuk merupakan tanaman lokal sebagai bahan pangan yang sudah dikenal secara turun temurun. Secara empiris digunakan masyarakat sebagai sayuran atau lalapan. Daun katuk mengandung senyawa bioaktif yang berpotensi sebagai sumber fortifikasi. Kandungan daun katuk tiap 100 gram kering, meliputi: kalori 59 kal, protein 6,4 gram, 
lemak 1 gram, hidrat arang 9,9 gram, serat 1,5 gram, abu 1,7 gram, kalsium $233 \mathrm{mg}$, fosfor $98 \mathrm{mg}$, besi 3,5 mg, karoten $10.020 \mu \mathrm{g}$, vitamin B dan C $164 \mathrm{mg}$, dan air 81 gram, (Azis, 2006). Selain itu, daun katuk juga mengandung senyawa yang memiliki efek laktagogum.

\section{PERUMUSAN MASALAH}

Berdasar uraian pada pendahuluan, maka perumusan masalah berupa pertanyaan penelitian sebagai berikut:

2.1. Apakah produk makanan megono laktagenik konvensional dan megono laktagenik dalam kemasan dapat diminati ibu menyusui?

2.2. Apakah produk makanan megono laktagenik konvensional dan megono laktogenik dalam kemasan dapat meningkatkan produksi ASI

2.3. Apakah produk makanan megono laktagenik konvensional dan megono laktogenik dalam kemasan dapat memacu pertumbuhan bayi?

\section{KAJIAN PUSTAKA}

\subsection{Nangka (Artocarpus heterophyllus Lmk)}

Nangka merupakan tanaman pohon yang berbuah, berasal dari India dan menyebar ke beberapa negara tropis sepreti Malaysia, Thailand, Filipina, Kamboja, Laos dan Vietnam termasuk Indonesia (Shi dan Moy, 2005 dalam Anna Amania Khusnayaini (2011).

Nangka termasuk tanaman hutan bercabang banyak, pohonya dapat mencapai tinggi 25 meter. Seluruh bagian tanaman mengandung getah, daunnya lonjong, bulat, dan lebar. Batang tanaman bersifat keras, apabila telah tua, batangnya berwarna kuning sampai kemerahan (Sunarjono, 1998 dalam Anna Amania Khusnayaini, 2011).

Buah nangka berbiji banyak, berkulit duri lunak. Setiap biji dibungkus oleh daging buah (endokarp), dan eksokarp yang mengandung gelatin. Buah nangka bervariasi dalam bentuk, ukuran, mutu karena ditanam dari biji. Daging buah tipis sampai tebal, berwarna putih saat mentah, dan berwarna kuning apabila sudah matang, berasa manis, dan beraroma spesifik (Sunarjono, 1998 dalam Anna Amania Khusnayaini, 2011).

Umumnya nangka masak dikonsumsi dalam bentuk buah segar, nangka muda banyak dijadikan sayur seperti Megono (Pekalongan), gudeg (Jogja dan Jawa Tengah), gulai dan pecel. Produk olahan daging buah nangka yang umum dijumpai adalah jus, wajik, pasta, dodol, sirup, dan produk awetan dalam kaleng. Daging buah nangka juga dapat dibuat pikel (asinan), kolak, manisan, dan sebagai pewangi minuman (Astawan, 2007 dalam Anna Amania Khusnayaini, 2011).

Nangka sangat mudah rusak pada suhu dingin, tetapi buahnya dapat dipertahankan setelah dipanen selama beberapa hari pada suhu $12^{\circ} \mathrm{C}$. Komposisi buah sekitar 75\% air, 25\% karbohidrat, dan sedikit protein (Rubatzky dan Yamaguchi, 1998 dalam Anna Amania Khusnayaini, 2011).

Nangka muda tiap 100 gram mengandung: air 85,4 g, energi 51,2 kkal, protein $2 \mathrm{~g}$, lemak 0,4 g, serat kasar 1,94 g, karbohidrat 11,3 g, kalsium $45 \mathrm{mg}$, fosfor $29 \mathrm{mg}$, Fe 0,5 mg, vitamin A 25 SI, vitamin B1 0,07 mg, vitamin C 9 mg (Depkes, 1981, Muchtadi, 1981 dalam Anna Amania Khusnayaini, 2011). 


\subsection{Megono}

Megono merupakan makanan berbahan dasar nangka muda khas dari daerah pantai utara (pantura) bagian barat. Megono merupakan salah satu menu makanan yang dikonsumsi oleh warga Pekalongan. Untuk membuat megono, nangka muda dicacah atau dicincang menjadi potongan-potongan kecil. Bahan pelengkap lain adalah parutan kelapa muda. Nangka muda dan parutan kelapa muda dikukus bersama aneka bumbu dapur yang sudah dihaluskan. Bumbu halusnya antara lain bawang putih, bawang merah, cabai merah, ketumbar, merica, kemiri, dan lengkuas. Biasanya ditambahkan pula daun salam, serai, dan bunga kecombrang.

Setelah matang, nangka muda, parutan kelapa, beserta bumbunya dicampur hingga merata dan disajikan, biasanya di atas nasi putih. konsep megono sangat sederhana, rasanya yang gurih menjadi pelengkap untuk nasi yang cenderung hambar. Megono dikonsumsi biasanya ditambahkan lauk lain seperti tempe mendoan, daging ayam, dan lain-lain.

Ketertarikan konsumen terhadap megono bukan hanya dari penampilan nangka muda yang dicincang, namun ada nilai rasa tertentu sehingga enak untuk dimakan. Sejalan dengan perkembangan masyarakat moderen terutama yang tinggal di Perkotaan megono menjadi makanan favorit di Pekalongan. Megono dapat ditemukan setiap saat, pagi hari, siang hari bahkan malam hari sekalipun. Di tepi-tepi jalan dan di warung makan tersedia megono.

Selain itu, Pekalongan juga menjadi tujuan wisata batik dan religius. Para wisatawan batik regional maupun manca negara berkunjung ke Kota Pekalongan. Banyak diantara pengunjung yang mencicipi megono khas Pekalongan, bahkan ada yang membawa pulang untuk dikonsumsi di rumah bersama keluarganya.

Permasalahanya adalah megono memiliki daya simpan pendek, sebab apabila lebih dari satu hari akan terjadi reaksi enzymatik oleh bakteri, yang menyebabkan tidak layak untuk dikonsumsi, serta penyajiannya masih dikemas atau dibungkus secara tradisional dengan daun pisang.

Penelitian tentang makanan kaleng berbahan dasar nangka muda sudah pernah dilakukan oleh Lembaga Ilmu Pengetahuan Indonesia (LIPI), menghasilkan gudeg dalam kaleng dengan kandungan gizi, antara lain: lemak 5,12\%, protein 5,33\%, Karbohidrat $12,47 \%$, Air $73,28 \%$, Abu1,72\% , yang memiliki daya simpan satu tahun (Lipi, 2010 dalam Anna Amania Khusnayaini, 2011).

\subsection{Daun Katuk}

Katuk merupakan tanaman perdu, dengan ketinggian mencapai 2-3 meter. Cabang-cabangnya agak lunak, daun tersusun selang-seling pada satu tangkai, daun berwarna hijau, berbentuk lonjong dengan panjang 2,5 cm, dan lebar 1,25-3 cm. Buah berbentuk bulat dicabang-cabang bawah daun. Di Indonesia tumbuh di dataran dengan ketinggian 0-2100 m di atas permukaan laut (Subekti, 2006) dalam Elbie Dwi Kencana (2012)

Daun katuk merupakan tanaman yang berpotensi sebagai laktagogum. Laktagogum merupakan zat yang dapat meningkatkan dan melancarkan produksi ASI. Sampai saat ini masyarakat masih percaya menggunakan laktagogum yang berasal dari bahan tradisional alamiah atau tanaman lokal, dibandingkan menggunakan produksi pabrik yang moderen atau sintetik. Penggunaan secara tradisional telah dibuktikan secara turun temurun. 
Hasil penelitian Kelompok Kerja Nasional Tumbuhan Obat Indonesia membuktikan bahwa tanaman katuk mengandung beberapa senyawa kimia, antara lain alkaloid papaverin, protein, lemak, vitamin, mineral, saponin, flavanoid, dan tanin yang berkasiat sebagai obat (Rukmana, 2003) dalam Elbie Dwi Kencana (2012)

Sa'roni (2004) dalam Erviana Duwi Sayekti (2016), membuktikan bahwa ibu menyusui yang diberikan ekstrak daun katuk dengan dosis 3 x $300 \mathrm{mg} /$ hari selama 15 hari dapat meningkatkan produksi ASI 50,7\% dibandingkan ibu menyusui yang tidak mendapatkan ekstrak daun katuk. Uji toksisitas akut dan teratogenik pada mencit membuktikan bahwa daun katuk tidak toksik dan tidak menimbulkan kecacatan pada janin (Lucia, E.W., Dayang, E.M dan Widayati S. 1997) dalam Erviana Duwi Sayekti (2016),

Azis (2006) dalam Erviana Duwi Sayekti (2016), melaporkan bahwa kandungan daun katuk tiap 100 gram, mengandung kalori 59 kal, protein 6,4 gr, lemak 1 gr, hidrat arang 9,9 gr, serat 1,5 gr, abu $1,7 \mathrm{gr}$, kalsium $233 \mathrm{mg}$, fosfor 98 $\mathrm{mg}$, besi 3,5 mg, karoten $10.020 \mu \mathrm{g}$, vitamin B dan C $164 \mathrm{mg}$, dan air $81 \mathrm{gr}$.

Pemanfaatan daun katuk secara empiris digunakan sebagai sayuran atau lalapan dan dipercaya masyarakat mampu melancarkan ASI. Namun, penggunaan tersebut dirasa kurang praktis, sebab dengan adanya peningkatan aktivitas dan tuntutan pekerjaan, masyarakat lebih memilih makanan siap olah dan siap santap. Untuk itu diperlukan upaya untuk membuat suatu produk alamiah yang fungsinya setara dengan bahan aslinya. Salah satu produk inovasi tersebut adalah megono laktagenik berbahan dasar daun katuk dan daun nangka muda.

\subsection{Air Susu Ibu (ASI)}

Air Susu Ibu (ASI) merupakan suatu emulsi lemak dalam larutan protein, laktosa, dan garam-garam anorganik yang disekresikan oleh kelenjar mamae ibu, yang berguna bagi makanan bayinya (Siregar, 2004 dalam Enok Nurliawati (2010). Jumlah produksi ASI setiap hari berkisar antara 450-1200 ml, rata-rata antara 750$850 \mathrm{ml}$.

Asi memiliki banyak manfaat dan keunggulan, baik aspek gizi, aspek imunologik, aspek psikologi, aspek kecerdasan, neurologis, ekonomis, dan aspek penundaan kehamilan (BPOM, 2009).

Secara fisiologis, terdapat beberapa jenis hormon yang berperan dalam mekanisme pembentukaan ASI. Hormon tersebut antara lain hormon progresteron berperan untuk merangsang pembentukan lobus dan alveoli, hormon estrogen memicu pelebaran duktus di kelenjar mammae serta merangsang hipofisis anterior dalam mengeluarkan prolaktin, dan human chorionic somatomammotropin (hCS) merupakan hormon plasenta yang berperan dalam sintesis enzim yang berguna untuk produksi ASI (Sherwood L, 2013), dalam Vincencius William, Michael Carrey (2016).

Pada semester awal kehamilan, kelenjar mammae telah mampu memproduksi ASI. Namun, kinerja hormon prolaktin dalam memproduksi ASI dihambat dengan tingginya kadar estrogen dan progresteron. Mekanisme tersebut berlanjut sampai sesaat sebelum plasenta dilahirkan. Pada saat plasenta lahir, kadar hormon estrogen dan progresteron menurun drastis, sehingga hormon prolaktin dapat bekerja mensekresi ASI (Sherwood L, 2013) dalam Vincencius William, Michael Carrey (2016). 
Setelah kelahiran, terdapat dua hormon lain yang bekerja untuk mempertahankan proses laktasi, yaitu hormon prolaktin untuk meningkatkan sekresi ASI, dan hormon oksitosin berguna dalam ejeksi ASI. Kedua hormon ini diragsang oleh refleks neuroendokrin saat bayi menghisap puting susu ibu (Sherwood L, 2013) dalam Vincencius William, Michael Carrey (2016).

Keadaan ini berlangsung selama 2-3 minggu, kadar serum prolaktin pada ibu post-partum yang tidak menyusui, akan kembali ke nilai normal seperti kondisi sebelum kehamilan. Pada ibu yang menyusui kadar serum prolaktin akan meningkat dengan adanya rangsangan puting susu. Kadar serum prolaktin meningkat dua kali lipat pada ibu yang menyusui dua bayi, dibanding ibu yang menyusui seorang bayi. Hal ini membuktikan bahwa serum prolaktin yang dilepaskan berbanding lurus dengan derajat rangsangan puting susu. Saat bayi menghisap puting susu, terjadi rangsangan saraf sensorik di sekitar areola. Impuls aferen dihantarkan ke hipotalamus mengawali pelepasan oksitosin dari hipofisis posteroir. Sesaat sebelum ASI keluar terjadi peningkatan hormon oksitosin, dan pelepasan hormon berlanjut setelah beberapa kali dilakukan penghisapan oleh bayi. Dalam waktu 20 menit setelah menyusui, kadar hormon oksitosin turun mendadak. Pelepasan oksitosin dihambat oleh katekolamin. Pelepasan katekolamin dirangsang oleh faktor stres dan nyeri (Anderson PO, Valdes V, 2007) dalam Vincencius William, Michael Carrey (2016).

Produksi ASI sangat dipengaruhi oleh faktor fisiologis, psikologis dan sosiologis.

\subsection{Pengaruh Laktagogum Terhadap Peningkatan Hormon-hormon Menyusui}

Isapan bayi merupakan mekanoreseptor pada puting susu ibu, yang merangsang hipotalamus untuk meningkatkan sekresi prolaktin releasing hormon, menurunkan prolaktin inhibiting hormon, merangsang pituitari posterior untuk memproduksi oksitosin. Oksitosin akan merangsang konstraksi sel-sel mioepitel di sekitar alveolus mammae dan menyebabkan pengeluaran ASI (ejection). Peningkatan hormon prolaktin akan merangsang pituitari anterior untuk memproduksi prolaktin yang akan menyebabkan sekresi ASI. Isapan bayi pada puting susu akan menekan siklus menstruasi dengan cara menghambat sekresi luteinzing hormon (LH) dan folikel stimulating hormon (FSH) (Kaliappan, 2008)

Perubahan hormon saat hamil menyebabkan kelenjar mammae dan penekanan aksis hipotalamus-pituitari-ovarium berkembang untuk laktasi dan amenore saat laktasi. Proses menghisap puting susu oleh bayi akan mengubah pola sekresi gonadotropin releasing hormon (FSH dan $\mathrm{LH}$ ) dan meningkatkan sensitivitas hipotalamus terhadap efek negatif estradiol.

Mekanisme ini akan menekan siklus ovarium saat laktasi, sehingga terjadi amenore saat laktasi (Moechherdiyaningsih, 1992). Saat kehamilan terjadi peningkatan hormon prolaktin, estradiol total, estradiol bebas, estron, estriol, progresteron, dan laktogen plasenta, sedangkan dehidroepiandrosteron sulfat menurun kadarnya. Estrogen (estradiol), estrogen (estriol) mempersiapkan pekerbangan kelenjar mammae untuk masa laktasi. Pada wanita yang lebih lama menyusui, terjadi peningkatan prolaktin dibandingkan wanita yang lebih pendek masa menyusui. Estradiol menekan aksis hipotalamus-pituitari-ovarum. Rasio kadar prolaktin terhadap estradiol dapat memprediksi lamanya terjadi masa amenore pada 
ibu menyusui (Mangathayaru, 2008). Berbagai substansi yang terdapat dalam laktagogum berpotensi menstimulasi hormon oksitosin dan prolaktin.

\subsection{Mutu Produk}

Mutu adalah hal-hal tertentu yang membedakan produk satu dengan lainnya, terutama berhubungan dengan daya terima dari kepuasan konsumen (Kramer dan Twigg, 1970 daam Anna Amania Khusnayaini, 2011). Mutu merupakan tingkat keunggulan produk pangan yang meliputi karakteristik utama yang menentukan tingkat penerimaan produk (Vaclavik dan Christian, 2008 dalam Anna Amania Khusnayaini, 2011).

Ada dua aspek untuk menilai mutu pangan, yaitu subjektif dan nonsubjektif. Atribut subjektif meliputi: penampakan, tekstur, dan flavor, sedangkan atribut objektif meliputi mutu gizi dan bakterial. Mutu gizi dan bakterial dapat diukur secara objektif dapat menggunakan analisis kimia, perhitungan jumlah bakteri, maupun uji spesifik lainnya (Szczesniak, 1983 dalam Anna Amania Khusnayaini, 2011).

Menurut Ahmed dan Shivhare (2006) dalam Anna Amania Khusnayaini (2011), sayuran yang telah diproses mengalami beberapa kehilangan mutu selama proses dan penyimpanan. Atribut mutu utama sayuran yang mengalami proses termal antara lain warna, aroma, rasa, dan tekstur. Selain itu, terdapat atribut mutu yang tersenbunyi seperti nilai gizi dan faktor keamanan (kimia dan mikrobial).

\section{BAHAN DAN METODE}

\subsection{Bahan dan Alat Penelitian}

Bahan untuk membuat megono meliputi; nangka muda, kelapa muda, bawang merah, bawang putih, kemiri, gula, garam, laos, ketumbar, terasi, daun jeruk, cabai merah, bunga kecombrang, batang serai dan serbuk daun katuk.

Alat dalam penelitian ini meliputi: aluminium foil, plastic wrap, timbangan digital, sendok, blender, pisau, talenan, baskom kecil, keranjang baskom, panci sarang, kompor gas dan gas, piring, sendok makan, serbet, kertas tissue. Alat untuk mengukur produksi ASI dan pertumbuhan bayi antara lain: timbangan bayi, gelasukur/botol susu, breast pump (pompa susu), meteran, kuesioner.

\subsection{Tahap Penelitian}

4.2.1. Tahap Pembuatan Formula

Pembuatan formula Megono mengikuti resep yang terdapat di masyarakat sudah berlaku secara turun-temurun. Akan diambil tiga resep megono yang cukup terkenal di masyarakat.Untuk memudahkan pengukuran, maka nangka muda, parutan kelapa dan bumbu-bumbu dikonversikan terlebih dahulu ke dalam ukuran Standar Internasional (SI), yaitu gram.

Penyiapan nangka muda dan parutan kelapa: bahan dasar : nangka muda dikupas, dipotong kecil-kecil, dicuci bersih, disisihkan, kelapa setengah tua dikupas dan diparut agak kasar.

Penyiapan bumbu:bawang merah, bawang putih, kemiri, gula, garam, ketumbar, lada, terasi, ditumbuk atau diblender. Cabai merah besar, lengkuas, dan bunga kecombrang diiris kecil, daun jeruk, serta batang serai yang sudah dikeprek.

Penyiapan daun katuk: Pilih daun katuk yang muda dan segar, disortasi, di-trimming, dicuci untuk membersihkan kotoran dan mikroba yang terdapat 
pada daun katuk, dilayukan selama 24-48 jam, kemudian digiling atau diblender.

Percampuran bahan baku: Setelah semua bahan sudah disiapkan, maka langkah selanjutnya adalah percampuran bahan baku. Percampuran bahan baku terdiri atas tiga formula dengan perbandingan bahan megono : bumbu : untuk tiap 200 gram ditambahkan serbuk daun katuk 1 gram.

\subsubsection{Tahap Pemasakan/Pengukusan}

Proses pemasakan konvensional melalui dua tahap, yaitu tahap pertama pengukusan nangka muda dan parutan kelapa, kemudian dilanjutkan tahap kedua dengan penambahan bumbu dan daun katuk. Pengukusan dalam panci bersarang selama 20 menit. Proses pemasakan meliputi dua tahap, yaitu tahap pengukusan nangka muda dan parutan kelapa, bertujuan untuk membentuk tekstur yang lunak, dan warna yang diinginkan. Tahap pemasakan kedua, yaitu pemasakan nangka muda dengan bumbu, dengan tujuan supaya bumbu meresap rata pada seluruh bagian nangka muda. Sebelum proses pemasakan, nangka muda terlebih dahulu dikupas, dipotong kecil-kecil, kemudian diblansir menggunakan air pada suhu $85^{\circ} \mathrm{C}$ selama 30 menit, dengan maksud menghilangkan getah nangka muda yang dapat mempengaruhi produk. Setelah megono masak, tahap selanjutnya yaitu pengemasan megono. Setiap kemasan (aluminium foil) diisi dengan 200 gram megono.

4.2.3. Tahap Uji Organoleptik Hedonik

Tahap selanjutnya yaitu dilakukan uji organoleptik hedonik terhadap produk megono, a) Formula I = nangka muda : bumbu-bumbu, b) Formula II = nangka muda : bumbu-bumbu, c) Formula III = nangka muda : bumbu-bumbu, berupa: warna, tekstur, rasa, dan aroma. Uji organoleptik digunakan untuk menguji tingkat penerimaan berupa warna, rasa dan tekstur denga uji rating hedonik (Acceptance Test). Uji organoleptik diujikan kepada 15 relawan yang berasal dari ahli gizi, ibu menyusui, dan penggemar makanan megono, sebagai panelis untuk mencicipi sampel, selanjutnya diminta untuk menilai tingkat kesukaan terhadap tekstur, warna, rasa dan aroma. Penilaian mutu produk menggunakan skala hedonik. Skor persepsi panelis mengacu pada skala (Meilgaard, 1999 dalam Anna Amania Khusnayaini (2011), yaitu: 1=sangat suka, 2=tidak suka, 3=agak tidak suka, 4=netral, 5=agak suka, 6=suka, 7= sangat suka

\subsubsection{Tahap Uji Kandungan Gizi}

Untuk menguji kandungan gizi yang terdapat pada produk megono konvensional dan megonolak tagenik diperlukan Uji Proksimat di Laboratorium Pangan Universitas Muhammadiyah Semarang. Uji komposisi megono dan megono laktagenik meliputi: nilai $\mathrm{pH}$, kadar air, kadar abu, protein, lemak, karbohidrat, dan serat.

Parameter analisa kadar protein menggunakan metode Kjedahl, analisa kadar lemak dengan metode Soxhlet, analisa kadar air dengan metode pengeringan di oven, analisa kadar abu dengan metode pengabuan, dan analisa karbohidrat menggunakan rumus: \% karbohidrat (gram/100gram)=100(protein+lemak+abu+air) (Sudarmaji dkk, 1996) dikutip oleh Anna Amania Khusnayaini (2011). 


\subsubsection{Tahap Uji Lapangan}

Formula megono laktagenik terpilih dimplementasikan kepada 24 responden ibu menyusui, terdiri atas 12 responden kelompok intervensi Ia diberikan megono laktagenik kemasan, dan 12 responden kelompok kontrol $\mathrm{Ib}$ diberikan makanan megono konvensional.

Responden pada kelompok Ia diminta mengkonsumsi makanan megono laktagenik kemasan dan kelompok Ib megono konvensional sebanyak 200 gram setiap hari. Pada hari I sebelum responden mengkonsumsi megono, terlebih dahulu dilakukan pretest terhadap BB bayi sebelum dan setelah menyusui dan volume ASI. Setelah pre test, responden diminta mengkonsumsi megono. Pengamatan dilakukan mulaidariminggu ke-0, minggu pertama, minggu kedua, dan minggu ketiga.

Pengukuran meliputi volume ASI dan antropometri bayi. Pengukuran volume ASI dilakukan dengan cara: menimbang berat bayi sebelum dan setelah menyusui antara jam 09.00-13.00 WIB seminggu sekali. Perbedaan bobot bayi sebelum dan sesudah disusui diasumsikan sebagai banyaknya ASI yang dihisap oleh bayi (WHO, 1985) dikutip oleh Anna Amania Khusnayaini (2011).

Volume ASI dihitung dengan rumus:

Volume ASI $(\mathrm{ml})=\underline{\text { bobot bayi }(\mathrm{g})}$

1,030

Bobot bayi : Perbedaan berat bayi sebelum dan sesudah disusui 1,030 : Berat jenis ASI (modifikasi Soedibyo, 1977; Tjahjadi, 1989, dikutip oleh Christin M.S, 2001)

Pada bayi yang tidak dapat menghabiskan ASI pada waktu tersebut, maka ASI dipompa keluar payudara, dan di ukur dengan gelasukur/ botolsusu. Sehingga volume ASI selama 4 jam didapatkan dari besarnya volume ASI yang disusukan kepada bayi ditambah sisa ASI yang dipompa keluar.

\section{ANALISIS}

Analisis pada penelitian ini, meliputi: analisis organoleptik terhadap warna, tekstur, rasa, aroma.

Analisis proksimat, meliputi: kadar protein dengan metode Kjedahl, analisa kadar lemak dengan metode Soxhlet, analisa kadar air dengan metode pengeringan dioven, analisa kadar abu dengan metode pengabuan, dan analisa karbohidrat menggunakan Rumus: \% karbohidrat (gram/100gram) $=100$ - (protein +lemak+abu+air), (Sudarmaji dkk, 1996), dikutip oleh Anna Amania Khusnayaini (2011) serta analisa pH menggunakan $\mathrm{pH}$ meter.

Uji Anova untuk menganalisis efektifitas megono konvensional dan megono laktagenik kemasan terhadap produksi ASI dan pertumbuhan bayi. 


\section{HASIL PENELITIAN DAN PEMBAHASAN}

\subsection{Uji Persepsional Organoleptik Hedonik}

Tabel 1 Uji Persepsional Organoleptik Hedonik

\begin{tabular}{lccccc}
\hline & & \multicolumn{4}{c}{ Skor nilai } \\
\cline { 3 - 6 } Resep & $\mathrm{N}$ & Rasa & Aroma & Tekstur & Warna \\
\hline Megono A & 15 & $\mathbf{8 7}$ & $\mathbf{8 4}$ & $\mathbf{8 9}$ & $\mathbf{8 6}$ \\
Megono B & 15 & 49 & 50 & 56 & 49 \\
Megono C & 15 & 54 & 52 & 50 & 54 \\
\hline
\end{tabular}

Tabel 1 membuktikan bahwa resep megono A secara keseluruhan memiliki nilai tertinggi. Pada atribut rasa nilai 87, atribut aroma 84, atribut tekstur 89 dan atribut warna 86,artinya resep megono A terpilih untuk dilanjutkan ketahap berikutnya yaitu uji proksimat, dan uji lapangan.

\subsection{Pertumbuhan Bayi}

\subsubsection{Kelompok Kontrol}

Hasil penelitianpertumbuhan bayi dari ibu yang diberikan megono konvensional dapat dilihat dari berat badan bayi seperti pada tabel 2. berikut:

Tabel 2 Distribusi Nilai Sentral Berat Badan Bayi pada Kelompok Kontrol

\begin{tabular}{lccc}
\hline \multicolumn{1}{c}{ Variabel } & N & Mean & Min-Max \\
\hline Berat badan bayi (pretest) & 12 & 4780 & $3450-6300$ \\
Berat badan bayi (minggu ke-1) & 12 & 4835,42 & $3510-6345$ \\
Berat badan bayi (minggu ke-2) & 12 & 4903,33 & $3580-6435$ \\
Berat badan bayi (minggu ke-3) & 12 & 4974,17 & $3650-6510$ \\
\hline
\end{tabular}

Tabel 2 menunjukkan bahwa berat badan bayi pada kelompok kontrol rata-rata 4.780 gram dengan berat badan minimum sebesar 3.450 gram dan maksimum sebesar 6.300 gram. Berat badan bayi pada kelompok kontrol mengalami peningkatan pada minggu ke-1, ke-2 dan ke-3. Rata-rata berat badan bayi pada minggu ke-3 sebesar 4.974,17 gram dengan berat badan minimum sebesar 3.650 gram dan berat badan maksimum sebesar 6.510 gram. Dapat disimpulkan bahwa rata-rata berat badan bayi pada kelompok kontrol mengalami peningkatan secara signifikan dari pre test sampai minggu ke-3 sebesar 197,17 gram.

\subsubsection{Kelompok Intervensi}

Hasil penelitian pertumbuhan bayi dari ibu yang diberikan megono laktogenik dapat dilihat dariberat badan bayi pada tabel 3. berikut:

Tabel 3 Distribusi Nilai Sentral Berat Badan Bayi pada Kelompok Intervensi

\begin{tabular}{lccc}
\hline \multicolumn{1}{c}{ Variabel } & N & Mean & Min-Max \\
\hline Berat badan bayi (pretest) & 12 & 6316,67 & $5150-7200$ \\
Berat badan bayi (minggu ke-1) & 12 & 6512,50 & $5330-7380$ \\
Berat badan bayi (minggu ke-2) & 12 & 6737,92 & $5555-7630$ \\
Berat badan bayi (minggu ke-3) & 12 & 7000,83 & $7630-7900$ \\
\hline
\end{tabular}


Tabel 3 menunjukkan bahwa berat badan bayi pada kelompok intervensi rata-rata 6.316,67 gram dengan berat badan minimum sebesar 5.150 gram dan maksimum sebesar 7.200 gram. Berat badan bayi pada kelompok intervensi mengalami peningkatan pada minggu ke-1, ke-2 dan ke-3. Rata-rata berat badan bayi pada minggu ke-3 sebesar 7.000,83 gram dengan berat badan minimum sebesar 7.630 gram dan berat badan maksimum sebesar 7.900 gram. Dapat disimpulkan bahwa rata-rata berat badan bayi pada kelompok intervensi mengalami peningkatan secara signifikan dari pre test sampai minggu ke-3 sebesar 684,26 gram.

\subsection{Volume ASI}

\subsubsection{Kelompok Intervensi}

Volume ASI dihitung berdasarkan berat badan bayi minggu ke-1 dikurangi pre test dan hasilnya dibagi dengan nilai konstanta 1,030., demikian pula untuk volume ASI pada minggu ke-2 dan minggu ke-3 dilakukan dengan cara yang sama. Hasil penelitian volume ASI bayi dari ibu yang diberikan megono dapat dilihat pada Tabel 4berikut:

Tabel 4 Distribusi Nilai Sentral Volume ASI Responden Kelompok Kontrol

\begin{tabular}{cccc}
\hline Variabel & N & Mean & Min-Max \\
\hline Volume ASI (minggu ke-1) & 12 & 53,80 & $39-78$ \\
Volume ASI (minggu ke-2) & 12 & 65,94 & $49-107$ \\
Volume ASI (minggu ke-3) & 12 & 68,77 & $49-97$ \\
\hline
\end{tabular}

Tabel 4 menunjukkan bahwa volume ASI pada kelompok kontrol untuk minggu ke-1 rata-rata 53,80 $\mathrm{ml}$, minggu ke-2 sebesar 65,94 $\mathrm{ml}$ dan minggu ke3 sebesar 68,77 ml. Berdasarkan hasil tersebut dapat disimpulkan bahwa volume ASI pada minggu ke-1 sampai minggu ke-3 mengalami peningkatan secara signifikan. Peningkatan volume ASI pada kelompok kontrol rata-rata sebesar $62,83 \mathrm{ml}$.

\subsubsection{Kelompok Intervensi}

Penghitungan volume ASI responden pada kelompok intervensi dilakukan dengan cara yang sama dengan penghitungan volume ASI responden pada kelompok kontrol. Hasil penelitian volume ASI bayi dari ibu yang diberikan megono laktagenikdapat dilihat pada tabel 5. berikut:

Tabel 5 Distribusi Nilai Sentral Volume ASI RespondenKelompokIntervensi

\begin{tabular}{cccc}
\hline Variabel & N & Mean & Min-Max \\
\hline Volume ASI (minggu ke-1) & 12 & 190,13 & $175-214$ \\
Volume ASI (minggu ke-2) & 12 & 218,85 & $194-243$ \\
Volume ASI (minggu ke-3) & 12 & 255,26 & $194-301$ \\
\hline
\end{tabular}

Tabel 5 menunjukkan bahwa volume ASI pada kelompok intervensi untuk minggu ke-1 rata-rata 190,13 ml, minggu ke-2 sebesar 218,85 ml dan minggu ke-3 sebesar 255,26 ml. Berdasarkan hasil tersebut dapat disimpulkan bahwa volume ASI responden kelompok intervensi pada minggu ke-1 sampai 
minggu ke-3 mengalami peningkatan secara signifikan. Peningkatan volume ASI pada kelompok intervensi sebesar 221, $413 \mathrm{ml}$.

\subsection{Efektivitas Megono Konvensional dan Megono Laktagenik Terhadap Pertumbuhan Bayi}

Pertumbuhan bayi dalam penelitian ini diukur berdasarkan berat badan bayi pre test, minggu ke-1, minggu ke-2 dan minggu ke-3. Hasil penelitian tentang pertumbuhan bayi dari ibu yang diberikan megono konvensional dapat dilihat pada tabel 6 berikut:

Tabel 6Pengaruh Megono Konvensional terhadap Pertumbuhan Bayi

\begin{tabular}{ccccc}
\hline Perlakuan & Mean & SD & F & p value \\
\hline Pre test & 4780 & 843,898 & 0,119 & 0,949 \\
Minggu ke-1 & 4835,42 & 846,805 & & \\
Minggu ke2 & 4903,33 & 846,574 & & \\
Minggu ke-3 & 4974,17 & 844,864 & & \\
\hline
\end{tabular}

Tabel 6 menunjukkan hasil uji ANOVA diperoleh $\rho$ value sebesar 0,949>0,05, sehingga Ho diterima yang berarti tidak ada perbedaan yang signifikan berat badan bayi dari ibu yang diberikan megono konvensional dari pre test, minggu ke-1, minggu ke-2 dan minggu ke-3.

Hasil penelitian tentang pertumbuhan bayi dari ibu yang diberikan megono laktagenik dapat dilihat pada tabel 7 berikut:

Tabel 7 Pengaruh Megono Laktagenik Terhadap Pertumbuhan Bayi

\begin{tabular}{ccccc}
\hline Perlakuan & Mean & SD & F & $\rho$ value \\
\hline Pre test & 6316,67 & 603,148 & 2,849 & 0,048 \\
Minggu ke-1 & 6512,50 & 600,365 & & \\
Minggu ke2 & 6737,92 & 601,753 & & \\
Minggu ke-3 & 7000,83 & 614,232 & & \\
\hline
\end{tabular}

Tabel 7 menunjukkan hasil uji ANOVA diperoleh $\rho$ value sebesar 0,048 < 0,05, sehingga Ho ditolak yang berarti ada perbedaan yang signifikan berat badan bayi dari ibu yang diberikan megono laktagenik dari pre test, minggu ke-1, minggu ke-2 dan minggu ke-3.

6.5. Efektivitas Megono Konvensional dan Megono Laktagenik Terhadap Volume ASI

Hasil penelitian volume ASI yang diberikan megono konvensional dapat dilihat padatabel 8 sebagai berikut:

Tabel 8 Pengaruh Megono Konvensional Terhadap Volume ASI

\begin{tabular}{|c|c|c|c|c|}
\hline Perlakuan & Mean & SD & $\mathbf{F}$ & $\rho$ value \\
\hline Minggu ke-1 & 53,80 & 10,025 & 4,126 & 0,025 \\
\hline Minggu ke2 & 65,94 & 15,690 & & \\
\hline Minggu ke-3 & 68,77 & 14,316 & & \\
\hline
\end{tabular}


Tabel 8 menunjukkan hasil uji ANOVA diperoleh $\rho$ value sebesar 0,025 < 0,05 , sehingga Ho ditolak yang berarti ada perbedaan yang signifikan volume ASI Ibu yang diberikan megono konvensional dari pre test, minggu ke-1, minggu ke-2 dan minggu ke-3.

Hasil penelitian volume ASI yang diberikan megono laktagenik dapat dilihat pada tabel 9 sebagai berikut:

Tabel 9 Pengaruh Megono Laktagenik Terhadap Volume ASI

\begin{tabular}{ccccc}
\hline Perlakuan & Mean & SD & F & $\rho$ value \\
\hline Minggu ke-1 & 190,13 & 11,306 & 17,027 & 0,000 \\
Minggu ke2 & 218,85 & 23,185 & & \\
Minggu ke-3 & 255,26 & 39,840 & & \\
\hline
\end{tabular}

Tabel 9 menunjukkan hasil uji ANOVA diperoleh $\rho$ value sebesar $0,000<0,05$, sehingga Ho ditolak yang berarti ada perbedaan yang signifikan volume ASI Ibu yang diberikan megono laktagenik dari pre test, minggu ke-1, minggu ke-2 dan minggu ke3.

\section{PEMBAHASAN}

\subsection{Pertumbuhan Bayi}

Berdasarkan data pada tabel 2 dan 3 di atas dapat diketahui bahwa peningkatan berat badan bayi tiap minggunya pada kelompok intervensi lebih besar yaitu 171,04 gram dari pada kelompok kontrol yaitu 78,5 gram. Berat badan bayi merupakan salah satu indikator pertumbuhan bayi. Hal ini sesuai dengan Wong (2009), yang menyatakan bahwa pertumbuhan adalah peningkatan jumlah dan ukuran besarnya sel di seluruh bagian tubuh yang secara kuantitatif dapat diukur. Pertumbuhan fisik merupakan hal yang kuantitatif atau dapat diukur, aspek peningkatan ukuran fisik individu sebagai hasil peningkatan dalam jumlah sel, indikator ukuran pertumbuhan meliputi perubahan tinggi dan berat badan, gigi, struktur skelet dan karakteristik seksual.

Berat badan bayi ibu yang diberikan megono laktagenik mengalami peningkatan rata-rata berat badan tiap minggunya sebesar 171,04 gram. Megono laktagenik merupakan megono yang dicampur daun katuk. Bayi dari ibu yang diberikan megono laktagenik mengalami peningkatan berat badan yang lebih besar karena daun katuk mengandung air sebesar 81 gram yang dapat memperlancar ASI. Hal ini sesuai dengan Rukmana (2007), yang menyatakan bahwadaun katuk 100 gram mengandung air 81 gram lebih tinggi dibandingkan daun singkong (77,2gram) dan daun pepaya (75,4gram).

\subsection{Volume ASI}

Peningkatan volume ASI pada kelompok kontrol rata-rata sebesar 62,83 ml. Peningkatan volume ASI pada kelompok intervensi rata-rata sebesar 221,413 ml. Berdasarkan hasil penelitian dapat disimpulkan bahwa volume ASI pada kelompok intervensi mengalami peningkatan yang lebih besar daripada kelompok kontrol.

Pemberian megono laktagenik pada ibu dapat meningkatkan produksi ASI karena dalam megono laktagenik mengandung daun katuk yang mempunyai kandungan air lebih banyak dibandingkan daun lainnya. ASI mempunyai kandungan 
utama air yang dapat diproduksi melalui daun katuk yang terkandung dalam mengono laktagenik.

Daun katuk dalam megono laktagenik dapat meningkatkan volume ASI dan daun katuk mempunyai peranan penting dalam pemenuhan gizi ibu menyusui karena dapat memperlancar produksi ASI dan mengandung laktagogum yang dapat meningkatkan produksi ASI. Hal ini sesuai dengan Sutomo (2010) yang menyatakan bahwa sayuran daun katuk dapat melancarkan produksi ASI karena mengandung laktagogum. Daun katuk juga kaya betakarotin (vitamin A), vitamin C, zat besi, fosfor, dan kalsium yang penting untuk ibu menyusui.

\subsection{Efektivitas Megono Konvensional dan Megono Laktagenik Terhadap Pertumbuhan Bayi}

Berdasarkan hasil penelitian dapat disimpulkan bahwa terdapat perbedaan peningkatan berat badan bayi baik dari ibu yang diberikan megono konvensional (kelompok kontrol) maupun ibu yang diberikan megono laktagenik (kelompok intervensi). Perbedaan peningkatan rata-rata berat badan pada kelompok kontrol tiap minggunya sebesar 78,5 gram, sedangkan pada kelompok intervensi sebesar 171,04 gram.

Perbedaan peningkatan pertumbuhan bayi antara kelompok kontrol dan kelompok intervensi dapat disebabkan kandungan daun katuk dalam megono laktagenik dapat meningkatkan produksi ASI dan mempunyai kandungan gizi yang setara daripada sayuran lainnya, sehingga dapat meningkatkan berat badan bayi setiap minggunya. Daun katuk dalam penelitian ini berfungsi sebagai sumber gizi bagi ibu. Kandungan gizi pada daun katuk dapat mempengaruhi kandungan gizi ASI. Rukmana (2007) menyatakan bahwa daun katuk bersifat multifungsi salah satunya sebagai sumber gizi. Produk utama tanaman katuk berupa daun yang masih muda (pucuk). Pucuk katuk potensial sebagai sumber gizi karena memiliki kandungan yang setara dengan sayuran lainnya seperti daun singkong dan daun pepaya.

Kandungan gizi yang cukup tinggi dalam daun katuk mempengaruhi kualitas kandungan nutrisi dalam ASI sehingga bayi akan mendapatkan asupan gizi yang sesuai dengan kebutuhan bayi untuk tumbuh kembang. Hal ini sesuai dengan Sutomo (2010) yang menyatakan bahwa komponen nutrisi ASI berasal dari sari makanan yang dikonsumsi ibu.

\subsection{Efektivitas Megono Konvensional dan Megono Laktagenik Terhadap Volume} ASI

Peningkatan volume ASI pada kelompok kontrol sebesar $62,83 \mathrm{ml}$ sedangkan pada kelompok intervensi sebesar 221,41 ml. Hasil penelitian ini dapat disimpulkan bahwa volume ASI ibu yang diberikan megono konvensional lebih kecil daripada volume ASI ibu yang diberikan megono laktagenik. Daun katuk dalam megono laktagenik mengandung air yang lebih tinggi dibandingkan sayuran lainnya seperti daun singkong dan daun pepaya. Kandungan air dalam daun katuk dapat meningkatkan produksi ASI ibu yang mengkonsumsi megono laktagenik yang mengandung daun katuk, sehingga dapat meningkatkan volume ASI.

Daun katuk juga mengandung senyawa aktif yang mampu merangsang hormon reproduksi wanita seperti hormon prostaglandin yang berfungsi merangsang produksi ASI. Hal ini sesuai dengan Apriadji (2007) yang menyatakan bahwa daun katuk mengandung sedikitnya tujuh senyawa aktif yang dapat merangsang 
pembentukan hormon-hormon. Hormon prostaglandin dapat menyuburkan perkembangan sel sekretoris yaitu sel-sel penghasil ASI dan memperlama jangka waktu dalam memproduksi ASI. Senyawa aktif lainnya membantu penyerapan gizi dan meningkatkan metabolismenya sehingga kapasitas produksi ASI meningkat.

Hasil penelitian ini Gunanegara (2012) yang menyatakan bahwa pemberian kapsul ekstrak daun katuk atau plasebo ternyata tidak berbeda secara bermakna, tapi setidaknya memberikan efek positif terhadap sugesti peserta penelitian untuk melanjutkan pemberian ASI, karena dari 80 orang peserta penelitian terdapat 74 orang yang terus menyusui ASI selama periode penelitian.

\section{SIMPULAN}

8.1. Rata-rata berat badan bayi pada kelompok kontrol mengalami peningkatan secara signifikan dari pre test sampai minggu ke-3 sebesar 197,17 gram. Rata-rata berat badan bayi pada kelompok intervensi mengalami peningkatan secara signifikan dari pre test sampai minggu ke-3 sebesar 684,26 gram.

8.2. Peningkatan volume ASI pada kelompok kontrol rata-rata sebesar $62,83 \mathrm{ml}$. Peningkatan volume ASI pada kelompok intervensi sebesar 221, $413 \mathrm{ml}$.

8.3. Tidak ada perbedaan yang signifikan berat badan bayi dari ibu yang diberikan megono konvensional dari pre test, minggu ke-1, minggu ke-2 dan minggu ke-3 dengan $\rho$ value sebesar $0,949>0,05$. Ada perbedaan yang signifikan berat badan bayi dari ibu yang diberikan megono laktagenik dari pre test, minggu ke-1, minggu ke-2 dan minggu ke-3 dengan $\rho$ value sebesar 0,048 < 0,05.

8.4. Ada perbedaan yang signifikan volume ASI ibu yang diberikan megono konvensional dari pre test, minggu ke-1, minggu ke-2 dan minggu ke-3 dengan $\rho$ value sebesar $0,025<0,05$. Ada perbedaan yang signifikan volume ASI ibu yang diberikan megono laktagenik dari pre test, minggu ke-1, minggu ke-2 dan minggu ke-3 dengan $\rho$ value sebesar $0,000<0,05$.

\section{SARAN}

\subsection{Dinas Kesehatan Kota Pekalongan}

9.1.1. Sebagai salah satu stokeholder yang bertanggung jawab terhadap kesehatan masyarakat, dapat menggunakan hasil penelitian ini untuk:

9.1.2. Sebagai sumber informasi tentang manfaat megono laktogenik dalam meningkatkan produksi ASI dan pertumbuhan bayi, sehingga dapat dijadikan bahan pertimbangan dalam mengimplementasikan kebijakan program ASI Eksklusif agar lebih berhasil.

9.1.3. Memanfaatkan kearifan lokal megono laktogenik sebagai salah satu kegiatan dalam program ASI Eksklusif pada bayi usia 0-6 bulan.

9.1.4. Melakukan kegiatan pembinaan dan pelatihan pada bidan untuk memanfaatkan megono laktogenik agar dapat diimplementasikan dalam program kelas ibu hamil sebagai upaya persiapan laktasi bagi ibu hamil agar program ASI Eksklusif pada bayi usia 0-6 dapat berhasil dengan baik dan dapat meningkatkan derajat kesehatan bayi dan anak.

\subsection{Petugas Kesehatan}

9.2.1. Petugas kesehatan dapat meningkatkan memberikan pendidikan kesehatan tentang manfaat megono laktogenik sebagai salah satu upaya meningkatkan 
produksi ASI dan memenuhi gizi bayi sehingga pertumbuhan bayi dapat berjalan dengan baik.

9.2.2. Petugas juga dapat memberdayakan kader kesehatan di lingkungan sekitar untuk memberikan informasi pada ibu tentang megono latogenik sehingga ibu dapat meningkatkan produksi ASI dan bayi dapat tumbuh kembang dengan baik.

\subsection{Bagi Responden}

Hasil penelitian ini digunakan sebagai sumber informasi tentang megono laktogenik bagi ibu menyusui, sehingga ibu dapat mengaplikasikan dalam kehidupan sehari-hari dengan mengkonsumsi megono laktogenik selama menyusui.

\section{DATAR PUSTAKA}

Anna Amania Khusnayaini (2011). Pengaruh Tingkat Sterilitas Pada Proses Pengalengan Terhadap Sifat Fisik Gudeg Yang Dihasilkan. Skripsi, FTP IPB. Bogor.

Apriadji, W.H. (2008). Beuty Salad: 8 Salad Buah dan Sayur Cita rasa Indonesia untuk Tampil cantik, Langsing dan Awet Muda. Jakarta: Gramedia Pustaka Utama

Azis, S dan S.R. Muktiningsih (2006). Studi Manfaat Daun katuk. Cermin Dunia Kedokteran. Pusat Penelitian dan Pengembangan Farmasi, Badan Penelitian dan Peengembangan Kesehatan. Departemen Kesehatan RI. Jakarta. No.151:48-50.

Badan Pengawasan Obat dan Makanan (BPOM), (2009). Herbal Untuk Menyusui. Jurnal Naurakos, Vol.IV/No.10, Juli 2009

Badriul Hegar (2013). Mengapa Asi Eksklusif Sangat Dianjurkan Pada Usia DI Bawah 6 bulan. http://www.idai.or.id/artikel/klinik/asi/

BPS Kota Pekalongan (2016). Profil Kesehatan Kota Pekalongan

Christin M.S, (2001). Khasiat Konsumsi Daun bangun-bangun Sebagai Pelancar Air Susu Ibu Menyusui Dan Pemacu Pertumbuhan Bayi. Tesis, Program Pasca Sarjana. Institut Pertanian Bogor.

Dahlan, M. Sopiyodin (2008). Seri Evidence based medicine, Langkah-langkah membuat proposal penelitian bidang kedokteran dan kesehatan. Jakarta: CV. Sagung Seto.

Dinas Perhubungan, Pariwisata dan Kebudayaan Kota Pekalongan (2016). Jumlah kunjungan wisata.

Elbie Dwi Kencana (2012). Pengaruh Suhu dan Lama Pengeringan Terhadap karakteristik Teh Herbal Daun Katuk. Jurnal Tugas Akhir, Fakultas Teknologi Pertanian, Universitas Pasundan.

Enok Nurliawati (2010). Faktor-faktor Yang Berhubungan Dengan Produksi Air Susu Ibu Pasca Seksio Saesaria Di Wilayah Kota Dan Kabupaten Tasik Malaya. Tesis, FIK -UI.

Erviana Duwi Sayekti (2016). Aktivitas Antioksidan Teh Kombinasi Daun katuk dan Daun Kelor dengan Variasi Suhu Pengeringan. Skripsi, Prodi Biologi FKIP UMS

Eryna Satyaningtyas, Teti Estiasih (2014). Roti Tawar, Perangsang ASI, Berbasis Kearifan Lokal Daun Katuk (Sauropus androgynus (L) Merr). Jurnal Pangan dan Agroindustri, 
Vol.2, No.1, p121-131, Januari 2014, Jurusan Teknologi Hasil Pertanian, FTP, Universitas Brawijaya Malang.

Gunanegara RF, Suryawan A, Sastrawinata US, (2012). Efektifitas ekstrak daun katuk dalam produksi air susu ibu untuk keberhasilan menyusui. JKM, 2(9):1005-17

Kaliappan ND, Viswanathan PK, (2008). Phaemacognostical studies on the leaves of Plectranthus amboinicus (Lour) sping. Int J Green Pharm;V1 2, issue 3:182-184

Kementerian Kesehatan Republik Indonesia (2014). Laporan Hasil Riset Kesehatan Dasar, Badan Penelitian Pengembangan Kesehatan. Jakarta: Kemenkes RI.

Kementerian Kesehatan Republik Indonesia (2016). Pedoman Pekan ASI Sedunia. Kemenkes RI, Direktorat Gizi Masyarakat.

Mangathayaru, Thirunurgan PD, Patel, et al (2008). Essential oil composition of coleus ambonicus Lour. Indian Journal of Pharmaceutical Science: 67(1):122-123

Moechherdiyantiningsih (1992). Khasiat jати Melahirkan Terhadap kenaikan Produksi Air Susu Ibu. Puslitbang Gizi, badan Litbangkes, Bogor.

Rukmana (2007), Katuk Potensi dan Manfaatnya. Penerbit Kanisius. Yogyakarta

Sa'roni, Tonny Sadjimin, Mochammad Sja'bani, Zulaela (2004). Effectiveness of the Sauropous Androgynus (L) Merr Leaf Extract in Increasing Mother's Breast Milk Production. Media Litbangkes, vol XIV No.3

Siti Rayhani Fadhila, Lina Ninditya (2016). Dampak Tidak Menyusui di Indonesia, Pekan ASI IDAI. www.idai.or.id/artikel/klinik/asi/nilai-nutrisi-air-susu-ibu, diakses tanggal 4 Maret 2017

Sri Hardjanti (2008). Potensi Daun Katuk sebagai Sumber Zat Pewarna Alami dan Stabilitasnya selama Pengeringan Bubuk dengan Menggunakan Binder Maitodekstrin. Jurnal Penelitian Saintek, Vol.13, No.1, April 2008. Universitas Mercubuana, Yogyakarta

Sutomo, Budi Anggraini, Yanti Dwi. (2010). Makanan Sehat Pendamping ASI. Jakarta. Demedia

Vincencius William, Michael Carrey (2016). Dopresindo Untuk Meningkatkan Produksi Air Susu Ibu (ASI). CDK-238/vol. 43. no.3

Wong, D.L, Hockenberry, M, et all. (2009). Buku Ajar Keperawatan Pediatrik. Alih Bahasa Monica Ester, (6 th ed). Volume 2. Jakarta. EGC 